\author{
Iwona Jażdżewska \\ Uniwersytet Łódzki \\ Wydział Nauk Geograficznych \\ Zakład Geoinformacji \\ iwona.jazdzewska@geo.uni.lodz.pl
}

\title{
MURAL JAKO ATRAKCJA TURYSTYCZNA W MIEŚCIE POPRZEMYSŁOWYM - PRZYKŁAD ŁODZI
}

\begin{abstract}
Abstrakt: W artykule zaprezentowano rozwój łódzkich murali w XXI w., przedstawiono opinie uczestników wycieczek organizowanych w 2014 r. przez Galerię Urban Forms, której głównym zadaniem jest nasycenie tkanki miejskiej sztuką uliczną oraz jej promocja. Ponadto wskazano zasięg oddziaływania łódzkich murali poprzez analizę: wspomnień zarejestrowanych i udostępnionych na YouTube, informacji w mediach lokalnych, krajowych i zagranicznych, opinii udostępnionych w Internecie na blogach i w galeriach turystów oraz miłośników sztuki ulicznej, a także prezentacji w galeriach na stronach internetowych autorów murali. Pozwoliło to na poszukiwanie odpowiedzi na pytanie: czy murale mogą być atrakcją turystyczną miasta poprzemysłowego, jakim jest Łódź?
\end{abstract}

Słowa kluczowe: murale, netnografia, miasto poprzemysłowe, Galeria Urban Forms, Łódź.

\section{WSTĘP}

Władze miast postindustrialnych poszukują produktów, które mogłyby zachęcić turystów do ich odwiedzenia, a przez to pośrednio przyczynić się do rozwoju ekonomicznego. Ich zabudowa poprzemysłowa i mieszkaniowa bywa w złym lub bardzo złym stanie. Zabytki związane $\mathrm{z}$ dziedzictwem poprzemysłowym nie są dostatecznie silnym magnesem przyciągającym turystów, a innych brakuje $\mathrm{w}$ tych miastach. $\mathrm{Z}$ tego powodu poszukują one alternatywnych pomysłów, które służyłyby zmianie wizerunku miasta. Jednym z nich może być sztuka uliczna, a w szczególności wielkoformatowe graffiti usytuowane na ścianach budynków, nazywane muralami, które posiadając walory estetyczne mogą przyciągnąć zainteresowanych tą sztuką do miasta i przyczynić się pośrednio do jego rozwoju ekonomicznego (KOSTER, RANDALL 2005).

Przestrzenie artystyczne, w tym głównie street art, mogą pełnić różne funkcje $\mathrm{w}$ przestrzeni publicznej (GRODACH 2009). Sztuka uliczna, będąca początkowo nielegalną i uznawaną za wandalizm, przekształciła się w legalną formę prezentacji artystycznych treści, która ma potencjał turystyczny. Taką drogę przeszły malowane na ścianach budynków murale w Filadelfii, w której władze początkowo usuwały nielegalne graf- fiti, po czym wprowadzily program uprawnionego malowania ścian (DICKINSON 2012), a następnie reklamowały się jako miasto murali. Podobnie postąpiły władze w Melbourne (YOUNG 2010). W dzielnicach Bostonu Roxbury i Dorchester podejmowane są działania promujące murale lokalnej społeczności (Wight 2006, cyt. za: SIEBER i in. 2012). W wielu miastach na świecie graffiti wielkoformatowe na ścianach budynków stanowi jeden z czynników lokalnego rozwoju ekonomicznego zarówno $\mathrm{w}$ przypadku miast małych, takich jak kanadyjska Wardena (Toronto), Churchbridge, Duck Lake, Moose Jaw czy Humboldt, w których początkowo służyły one ich upiększeniu, a następnie stały się atrakcją turystyczną (KOSTER, RANDALL 2005, KOSTER 2008, WIGHT 2006), jak i dużych - np. Filadelfia, Chicago, Lyon. Niosą one również polityczne przesłanie (ARREOLA 1984) - w Betlejem graffiti umieszczono na murze oddzielającym to palestyńskie miasto od Jerozolimy, przypominając o aktualnym konflikcie na tym terenie (LARKIN 2014), w czasach Portugalii Salazara malowidła na murach służyły propagandzie państwa faszystowskiego (SAPEGA 2002), a w Iranie propagandzie Islamskiej Rewolucji (GRUBER 2008). 
Murale stały się wizytówką wielu miast, a ich zwiedzanie włączono do oferty turystycznej. W latach 80. ubiegłego wieku były one proponowane do zwiedzania lokalnej filadelfijskiej społeczności (ARREOLA 1984). Obecnie w Filadelfii projekt „Philadelphia Mural Arts Program” słynie już z ponad 3600 prac. Graffiti, które znajdują się w przestrzeni miejskiej, tworzą obecnie jedną $\mathrm{z}$ największych tego typu galerii, a Filadelfia stała się miastem rozpoznawalnym jako „miasto murali". Biura turystyczne oferują różne trasy zwiedzania; istnieje możliwość wyboru środka transportu: małe busy - "trolley tours”, rowery - „bike tours”, pieszo - "mural mile walking tour", specjalny pociacg - "love letter train tour". Ponadto przygotowano ofertę szlaków tematycznych dla grup zorganizowanych (sport, religie świata, osobowości miasta Filadelfii). Wydawane są certyfikaty uczestnictwa, a także sprzedawane różne gadżety, np. mural arts cap (https://www.mu ralarts.org/tours/).

W Europie bogatą ofertę turystyczną zwiedzania murali ma francuski Lyon, gdzie m.in. w osiedlu projektowanym przez Toniego Garniera znajduje się wiele wielkoformatowych murali. Można je podziwiać w ramach wycieczek pieszych organizowanych przez biuro turystyczne Office du Tourisme et des Congrèsdu Grand Lyon. Oprócz uczestniczenia w wycieczkach turysta może skorzystać z aplikacji na iPhon, dzięki której może wybrać murale na mapie - w różnych dzielnicach Lyonu, wokół Lyonu, we Francji czy w innych częściach świata, korzystać z geolokalizacji, a także znaleźć murale za pomocą słów kluczowych lub adresu internetowego (www.en.lyonfrance.com/).

W Polsce sztuka uliczna jest coraz bardziej widoczna, można wskazać wiele przykładów miast, w których murale stanowią atrakcję turystyczną, np. w dzielnicy Zaspa w Gdańsku czy w dzielnicach Wilda, Jeżyce, Garbary, Śródka w Poznaniu (ŚWIEŚCIAK i in. 2015). Łódzkie murale były przedmiotem analiz J. MOKRAS-GRABOWSKIEJ (2014) oraz M. ŚWIEŚCIAKA i in. (2015).

Celem głównym autorki artykułu jest przedstawienie, szersze niż u wymienionych autorów, rozwoju łódzkich murali w XXI w., wskazanie zasięgu przyciągania turystów ze świata oraz poznanie opinii uczestników wycieczek organizowanych w roku 2014 przez Galerię Urban Forms na ich temat. Celem szczegółowym jest poszukiwanie odpowiedzi na pytanie, czy murale mogą być atrakcją turystyczną Łodzi?

\section{OBSZAR BADAŃ}

Łódź jest trzecim co do liczby mieszkańców polskim miastem, położonym około $120 \mathrm{~km}$ na południowy zachód od Warszawy. Ma odmienną genezę niż inne duże - głównie średniowieczne - miasta w Polsce (np. Kraków, Poznań, Wrocław). Jego spektakularny rozwój przypadł na XIX w., kiedy władze Królestwa Polskiego postanowiły ulokować $\mathrm{w}$ mieście przemysł włókienniczy. Od tej pory zwane było ono „ziemią obiecaną" i świetnie zostało opisane przez laureata nagrody Nobla Władysława Reymonta w książce pod tym tytułem (którą na potrzeby filmu adaptował Andrzej Wajda1). Rozwój miasta był wówczas żywiołowy, zwiększało ono bardzo szybko liczbę mieszkańców oraz układ i zasięg przestrzenny (KOTER 1990). W drugiej połowie XX w. przemysł włókienniczy i odzieżowy dominował w Łodzi aż do roku 1989, tj. do transformacji ustrojowej w Polsce. Przez kilka dekad po II wojnie światowej miasto było niedoinwestowane, a XIX-wieczne secesyjne kamienice w jego centrum zostały zasiedlone w dużej części przez robotników i nie były odpowiednio utrzymywane. Na potrzeby poszerzenia ulic (np. Zachodnia, Narutowicza) wyburzono frontowe reprezentacyjne części budynków, pozostawiając zdegradowane oficyny. $W$ okresie socjalistycznym władze inwestowały w osiedla blokowe, które budowano w większości z dala od centrum. Taki stan trwał aż do 1989 r.

Po roku 1990 władze samorządowe systematycznie rewitalizują poszczególne budynki mieszkalne w centrum, powstają nowe bardzo interesujące projekty, np. Manufaktura, która w 2007 r. została finalistką prestiżowej nagrody ULI Awards for Excellence, przyznawanej przez Urban Land Institute. Był to projekt, w ramach którego firma APSYS przekształciła XIX-wieczny kompleks fabryczny Izraela K. Poznańskiego o powierzchni 27 ha w komercyjny kompleks handlowy, rozrywkowy, kulturalny, hotelowy, który stał się wizytówką miasta. Drugim projektem realizowanym od roku 2008 do chwili obecnej jest przekształcenie kompleksu składającego się z zabudowań elektrowni (z 1906 r.) oraz dworca Łódź Fabryczna (90 ha) w centrum festiwalowo-kongresowe, obiekty wystawiennicze, planetarium oraz studio filmowe. Władze miasta bardzo starają się, aby obraz biednej, brudnej, przemysłowej Łodzi zmienić w wizerunek miasta kreatywnego, pełnego pomysłów, nawiązującego do Łódzkiej Szkoły Filmowej², a także sztuki łódzkich artystów - Katarzyny Kobro i Władysława Strzemińskiego, którzy budowali awangardowe oblicze miasta w latach 30. XX w. Jak stwierdziła J. MOKRAS-GRABOWSKA (2010), w postindustrialną przestrzeń miasta doskonale wpisują się działania $\mathrm{z}$ zakresu sztuki nowoczesnej, przemysłu kreatywnego i szeroko pojętej kultury „offowej”.

Pomimo wielu starań władz miasta niemożliwe jest w tak krótkim czasie (ok. 25 lat po transformacji) odrobienie wszystkich zaniedbań z czasów wojny i okresu socjalistycznego. W centrum miasta w bliskiej odległości głównej jego ulicy - Piotrkowskiej (mniej 
niż 200 m) - znajduje się wiele budynków szpecących miasto, które są w bardzo złym stanie. Im dalej od głównej ulicy miasta można spotkać coraz więcej takich budynków. Zadziwiają one przybyszy, którzy po raz pierwszy odwiedzają Łódź, niekiedy są nimi zszokowani, ale akceptują je, tak jak np. organizatorzy Meeting of Styles (Graffiti-Hip-Hop-Event), którzy w 2005 r. zorganizowali w Łodzi spotkanie, a o mieście tak pisali:

To grzeszne miasto, w którym bardzo dużo się dzieje. Idąc przez nie, znajdziesz wiele szarawych ścian, przyjemną, starą architekturę w złym stanie - bardzo zniszczoną - oraz wiele, wiele śladów wyburzeń, zwisające części budowli i pośpiesznie stawiane konstrukcje $^{3}$.

Dostrzegli oni potencjał miasta, który można wykorzystać na sztukę uliczną.

\section{MURALE ŁODZI}

Najbardziej rozpoznawalnym ze względu na liczbę i jakość murali w świecie miastem polskim stała się Łódź. Pierwsze wielkoformatowe murale powstawały tu w latach 60. XX w., w okresie socjalistycznym. Łódź była wówczas miastem $\mathrm{z}$ dominacją przemysłu włókienniczego, odzieżowego, dlatego wiele spośród 200 murali $\mathrm{z}$ tego okresu prezentowało właśnie te zakłady przemysłowe (np. Zakłady Przemysłu Jedwabniczego "Pierwsza”, Zakłady Przemysłu Dziewiarskiego „Olimpia” lub „Lido”, Zakłady Przemysłu Bawełnianego im. Armii Ludowej "Alba”, Fabryka Dywanów „Dywilan” - http:/ / www.murale.mnc. pl/ i/mu_eng. pdf). Autorami projektów byli absolwenci wyższych szkół plastycznych, m.in. Państwowej Wyższej Szkoły Sztuk Plastycznych w Łodzi. Najbardziej znanymi artystami z tego okresu byli: Andrzej Feliks Szumigaj, grupa Arabski-Jaeschke-Tranda, Zdzisław Fryczka, Zbigniew Łopata, Bogumił Łukaszewski i Roman Szybilski (STĘPIEŃ 2010). Obecnie wiele $z$ tamtych murali nie istnieje lub są w bardzo złym stanie.

Renesans wielkoformatowych graffiti malowanych na murach w Łodzi nastąpił na początku wieku XXI. Pierwszy pomysł namalowania muralu w Łodzi zrodził się w 2000 r. podczas akcji „Kolorowa Tolerancja”, której celem było przeciwstawianie się nietolerancji, ksenofobii i wandalizmowi. W roku 2001 powierzono grupie Design Futura z Polski zadanie namalowania muralu, a do dyspozycji miała aż $960 \mathrm{~m}^{2}$ muru w centrum miasta, przy głównej jego ulicy - Piotrkowskiej (fot. 1).

Rok później, w 2002, odbył się w Łodzi pierwszy Międzynarodowy Festiwal Graffiti - Meeting of Styles (http://www.meetingofstyles.com/blog/lodzpoland/). Była to impreza organizowana od pięciu lat w różnych europejskich miastach, m.in. w Paryżu, Berlinie, Kopenhadze, Zagrzebiu, goszcząca również w wielu miastach świata. W jej trakcie zamalowano ponad 2,5 tys. $\mathrm{m}^{2}$ ścian dawnej hali fabrycznej. Rok później prezydent miasta nie wydał zgody na przeprowadzenie w Łodzi II edycji festiwalu. W latach 2004-2006 wznowiono festiwal, a uczestnikom oddano do dyspozycji m.in. 200-metrowy mur przy dworcu Łódź Kaliska oraz w innych częściach miasta. Mury zamalowały osoby z różnych krajów, m.in. z Niemiec (Stohead, DaddyCool, Cazo, Dome), Hiszpanii (Okuda), Węgier (Breakone, Heat), Białorusi (Pour), Anglii (Connor, Xenz), Portugalii (Kayo Klit, Kraft, Bugster), Szwajcarii (Nada One), Francji (Marco) - http:/ / www. meetingofstyles.com/.

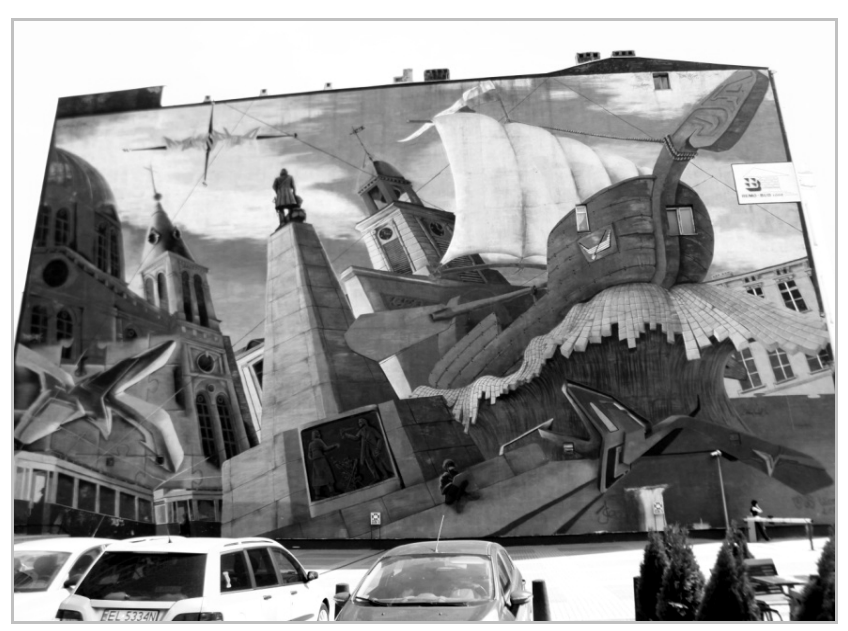

Fot. 1. Mural Design Futura (Polska) - „Łódka” z 2001 r. (fot. D. Chraścik, 2016)

Po rocznej przerwie w latach 2008-2010 zorganizowany został w Łodzi Outline Colour Festival, w ramach którego amerykańscy malarze z Nowego Jorku z grupy Tats Cru namalowali kolejny mural wielkoformatowy. Jego realizację można obserwować na portalu YouTube (https:/ / www.youtube.com/...). Miłośnicy graffiti z Polski i zagranicy (Maclaim z Niemic, NDEC z Japonii, Cactus \& Maria i Macsz z Włoch, Hemper z USA, Stan z Rosji, Pornostars z Hiszpanii) realizowali swoje pomysły na murach m.in. na terenach stuletniej dawnej fabryki Juliusza Kindermanna przy ulicy Łąkowej, która w okresie II wojny światowej byłą filią Fabryki Telefunken, na garażach, a także betonowych płytach w parku Baden-Powella. Dodatkową atrakcją było malowanie tramwaju, autobusów łódzkiego MPK oraz wagonów kolejowych. Jego organizatorzy zadbali również o atrakcje związane z muzyką hip-hop, a także breakdance, beatboxing i rap.

W tym samym czasie w 2009 r. powstała w Łodzi Fundacja Urban Forms, której działalność ogniskuje się wokół szeroko pojętej kultury miejskiej, m.in. na 
organizacji, promocji oraz wspieraniu inicjatyw artystycznych, edukacyjnych i społecznych. Celem, jaki postawiła sobie fundacja, jest nasycenie tkanki miejskiej sztuką uliczną. Galeria, która powstaje pod jej auspicjami staje się wizytówką i unikatową atrakcją turystyczną Łodzi. Co roku jesienią organizowane są festiwale, podczas których w krótkim czasie powstają nowe murale (http://www.urbanforms.org/about/en/). Stawały się one coraz bardziej popularne i zaczęły powstawać również z inicjatywy mieszkańców lub innych instytucji, np. UniQE ART.

Murale - a w szczególności murale wielkoformatowe - spowodowały, że w przestrzeni miejskiej Łodzi pojawiła się nowa przestrzeń turystyczna, wyróżniająca miasto, będąca symbolem nowoczesności, mody, wzbogacenia miasta $\mathrm{w}$ warstwie materialnej czy podniesienia jego statusu (MOKRAS-GRABOWSKA 2014). Organizowane przez Fundację Urban Forms wycieczki przyczyniają się do poszerzenia spektrum atrakcji turystycznych miasta, a także zapewniają uczestnikom nowe oryginalne przeżycia związane ze sztuką uliczną. Mogą wzbudzać coraz większe zainteresowanie i stać się impulsem do wzrostu ruchu turystycznego.

\section{METODY I ŹRÓDŁA DANYCH}

Przystępując do realizacji postawionego przez autorkę zadania badawczego wykorzystano źródła danych pozyskane $\mathrm{w}$ trakcie badań terenowych oraz w wyniku kwerendy stron internetowych związanych $\mathrm{z}$ tą tematyką. Część z nich można zaliczyć do netnografii, czyli formy badań etnograficznych prowadzonych w sieci internetowej mającej na celu analizę portali społecznościowych, blogów i stron internetowych (KOZINETS 2002, 2012).

Przegląd źródeł internetowych, w których wspominano o łódzkich muralach miał na celu poznanie tła historycznego ich powstania, a także opinii internautów na ich temat zarówno w Polsce, jak i za granica. Wyszukiwano ich na blogach, w galeriach fotograficznych, magazynach o sztuce, czasopismach, na You Tube w języku polskim, angielskim, francuskim, włoskim, hiszpańskim. W wyszukiwarkę internetową wpisywano tagi, czyli słowa kluczowe: \#mural lub \#murals, \#graffitti, \#Łódź lub \#Lodz, \#Urban Forms Gallery, \#streetart.

Inwentaryzacja terenowa miasta miała za zadanie wskazanie dokładnej lokalizacji murali, a także ich dokumentację fotograficzną. W celu poznania opinii uczestników wycieczek organizowanych w 2014 r. przez Galerię Urban Forms na temat łódzkich murali zastosowano kwestionariusz ankiety, który zawierał pytania dotyczące oceny wycieczki. Badania były pro- wadzone przez cały rok 2014. Kwestionariusz był rozdawany zazwyczaj pod koniec wycieczki, gdy uczestnicy mieli już wyrobioną opinię o zrealizowanym programie. Z obserwacji można było wywnioskować, że ankiety były wypełniane rzetelnie. Większość osób z chęcią odpowiadała na pytania, tylko nieliczni odmawiali udziału w badaniach. Odpowiedzi udzieliły 762 osoby, co stanowiło $78 \%$ wszystkich uczestników wycieczek. Pierwsza część kwestionariusza zawierała pytanie filtrujące - „Czy jest Pan/Pani mieszkańcem Łodzi?", po czym przyjezdnych dodatkowo pytano o główny cel wizyty, a także plany spędzenia czasu wolnego w mieście, zadając pytanie: "Jakie inne atrakcje turystyczne planuje Pan/Pani odwiedzić w czasie swojego pobytu w Łodzi?". Na drugą część ankiety odpowiadali wszyscy badani. Pytano m.in. o źródło informacji o wycieczce, o ocenę jej organizacji oraz poproszono o udzielenie odpowiedzi na kolejne pytanie: „Czy uważa Pan/Pani, że wielkoformatowe murale mogą stać się wizytówką Łodzi?". Całość kończyły dane metryczkowe.

Do interpretacji wyników został też wykorzystany raport $\mathrm{z}$ badań jakościowych autorstwa A. GRALIŃSKIEJ-TOBOREK i W. KAZIMIERSKIEJ-JERZYK (2014) pt. Experience of Art in Urban Space Urban Forms Gallery 2011-2013. Autorki zorganizowały badania jakościowe z 454 osobami - przechodniami lub przebywającymi w sąsiedztwie muralu - których udało się nakłonić do dłuższej rozmowy. Podstawowymi narzędziami badawczymi były scenariusze rozmowy oraz dyspozycje do wywiadu. Byli to przede wszystkim łodzianie, ale także osoby przyjezdne, pracujące lub uczące się w Łodzi.

\section{WYNIKI BADAŃ}

W roku 2015 było w Łodzi 36 murali autorstwa 61 artystów, których powstanie inicjowała Fundacja Galeria Urban Forms. Znajdowały się one na terenie całego miasta, ale największe skupisko odnotowano w jego centrum. Malowane były zarówno na ścianach XIX- i XX-wiecznych kamienic (fot. 2, 3, 6, 7), jak i ścianach szczytowych bloków wielorodzinnych (fot. 3, 4), rzadko budynków usługowych (fot. 5). Wiele z nich powstało na ścianach budynków wymagających remontu (fot. 2), co pozwala przypuszczać, że w niedługim czasie znikną z przestrzeni miasta. Były też prace zrealizowane na świeżo rewitalizowanych budynkach, podkreślając ich wyjątkową urodę (fot. 3).

Większość wielkoformatowych graffiti została namalowana, ale są też inne techniki prezentacji, np. twarz kobiety wykuta na ścianie kamienicy przez Portugalczyka Vhilsa czy instalacja Polaka - Łukasza Ber- 


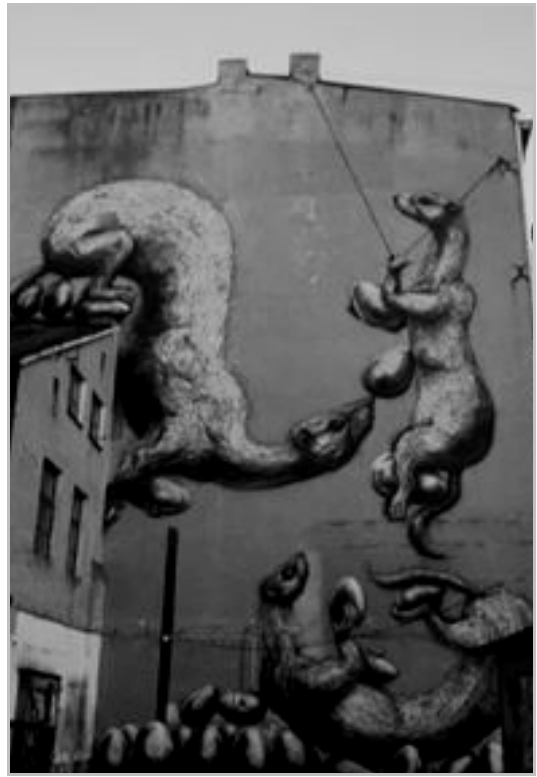

Autor: Roa (Belgia)

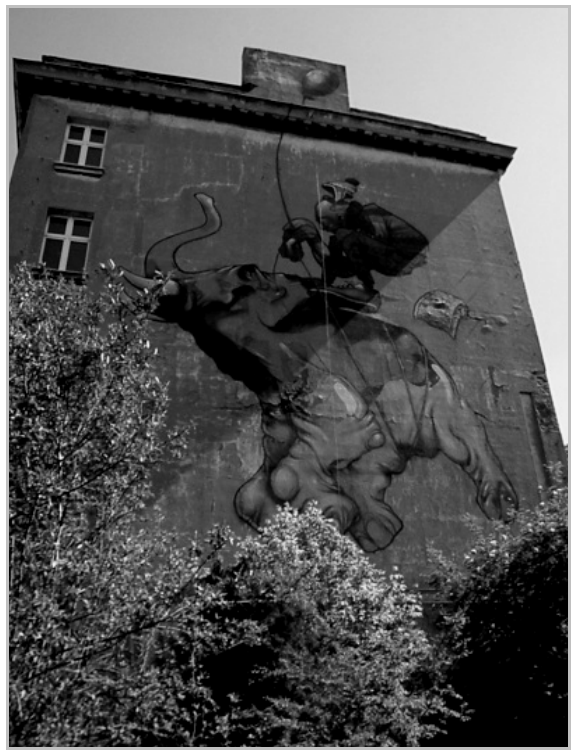

Autor: Etam Crew (Polska)

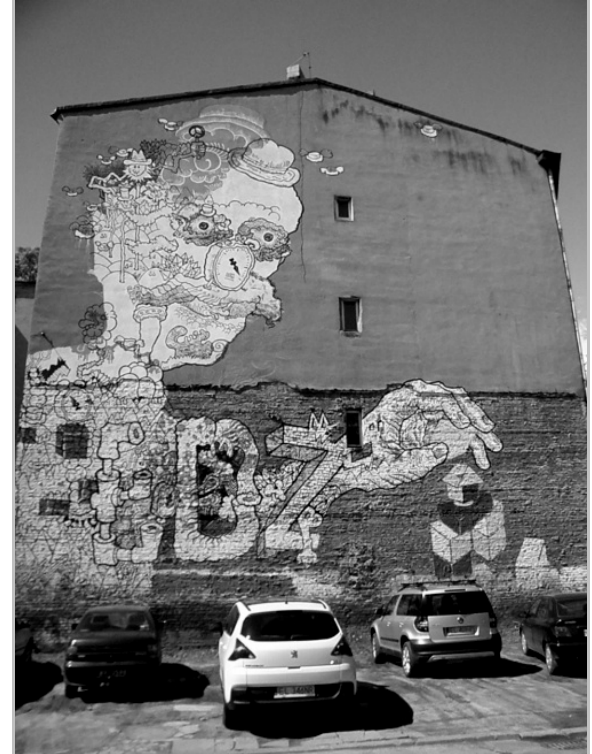

Autor: Gregor (Polska)

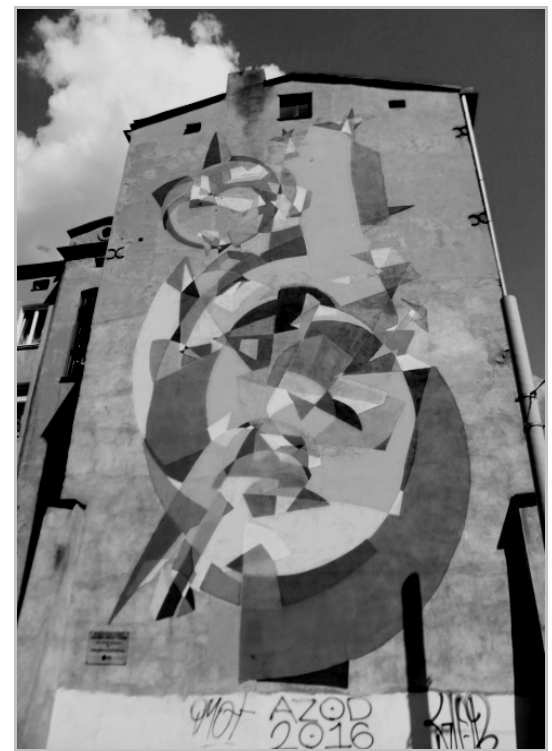

Autor: Kenor (Hiszpania)

Fot. 2. Murale zrealizowane w centrum Łodzi na ścianach szczytowych budynków wymagających remontu (fot. D. Chraścik, 2016)

gera, wykonana z 1300 olbrzymich gwoździ ważących ponad pół tony, z napisem "Cisza" (fot. 6). Trzecią imponującą instalacją jest ptak jerzyk, którego Portugalczyk - Artur Bordalo (znany jako Bordalo II) wykonał $\mathrm{z}$ materiałów pochodzących $\mathrm{z}$ recyklingu i kolorowych farb (fot. 7).

Tematyka murali była bardzo różnorodna i trudno wskazać dominujące motywy, jednak kilku artystów odniosło wybrany temat do miasta, w którym realizowali prace. Należy do nich jedna z pierwszych prac o nazwie „Łódka” (fot. 1), usytuowana przy głównej ulicy miasta - Piotrkowskiej 152, której powstanie da- tuje się na $2001 \mathrm{r}$. Praca zajmuje około $960 \mathrm{~m}^{2}$ powierzchni i była wówczas największym muralem na świecie. Ciekawostką jest, że podczas jego powstawania zużyto 2000 puszek ze sprayem (www.lodz.wyborcza. $\mathrm{pl} / \ldots$, www.expressilustrowany.pl/..., www.murale. mnc.pl/...). Drugą pracą był pocztówkowy mural wykonany przez grafficiarzy $\mathrm{z}$ nowojorskiej grupy Tats Cru, który zajął powierzchnię $733 \mathrm{~m}^{2}$, a powstał w ramach odbywającego się X Międzynarodowego Festiwalu Sztuki Graffiti Outline Colour Festival 2010 w Łodzi (fot. 8). 


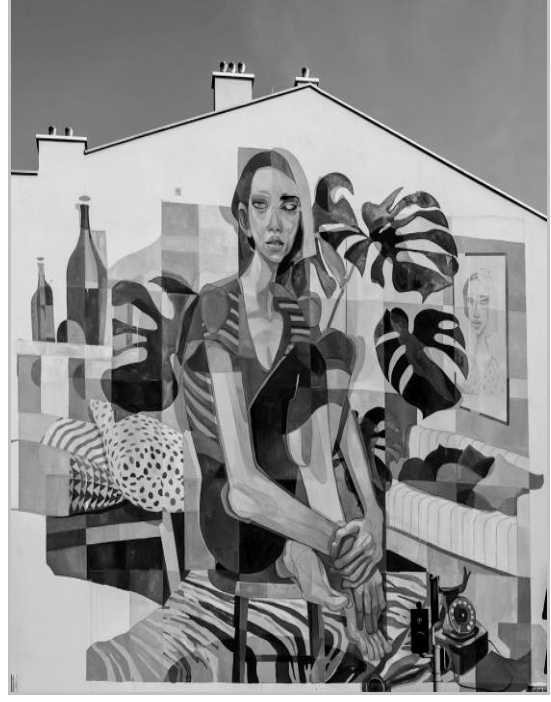

Autor: Morik (Rosja), (fot. I. Jażdżewska)

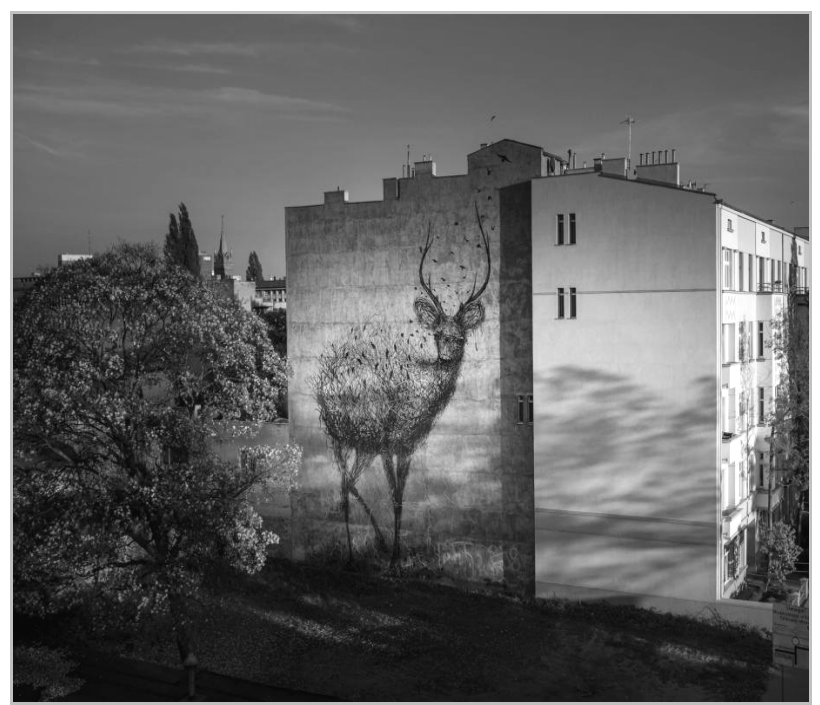

Autor: Daleast (Chiny)

Źródło: www.galeriaurbanforms.org

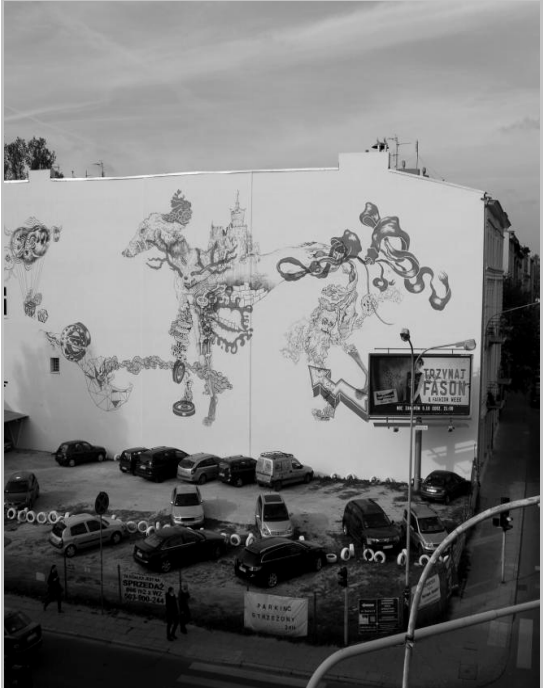

Autor: Gregor (Polska) Źródło: http://www.galeriaurbanforms.org

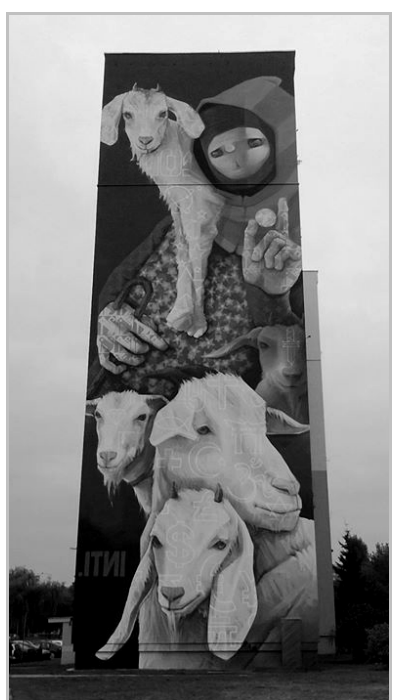

Autor: Inti (Chile) (fot. D. Chraścik, 2016)

Fot. 3. Murale zrealizowane w centrum Łodzi na ścianach szczytowych wyremontowanych budynków

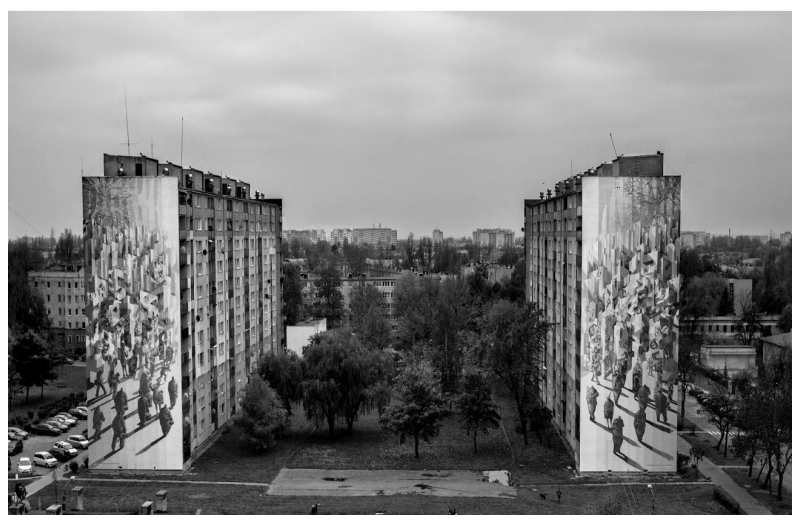

Fot. 4. Murale znajdujące się poza centrum Łodzi, na ścianach szczytowych budynków wielorodzinnych - autor: Proembrion/Chazme/Cekas/Tone/Sepe (Polska) Źródło: http://chazme718.blogspot.com/

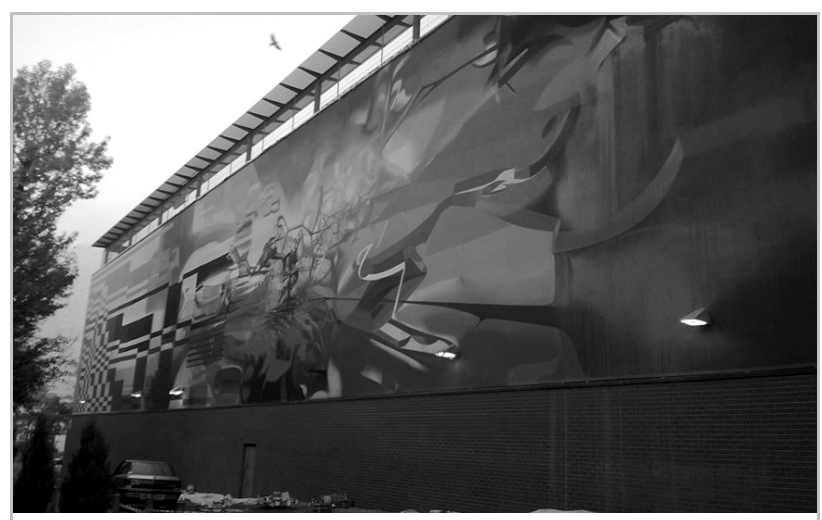

Fot. 5. Mural w centrum Łodzi na ścianie szczytowej galerii handlowej

- autor: Proembrion (Polska) (fot. I. Jażdżewska) 


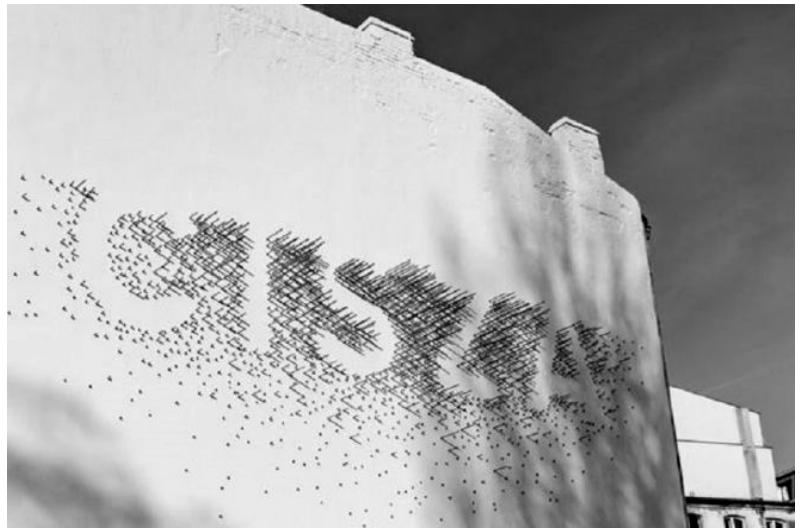

Fot. 6. Mural/instalacja wykonana z gwoździ na ścianie szczy towej kamienicy - autor: Łukasz Berger (Polska) (fot. I. Jażdżewska)

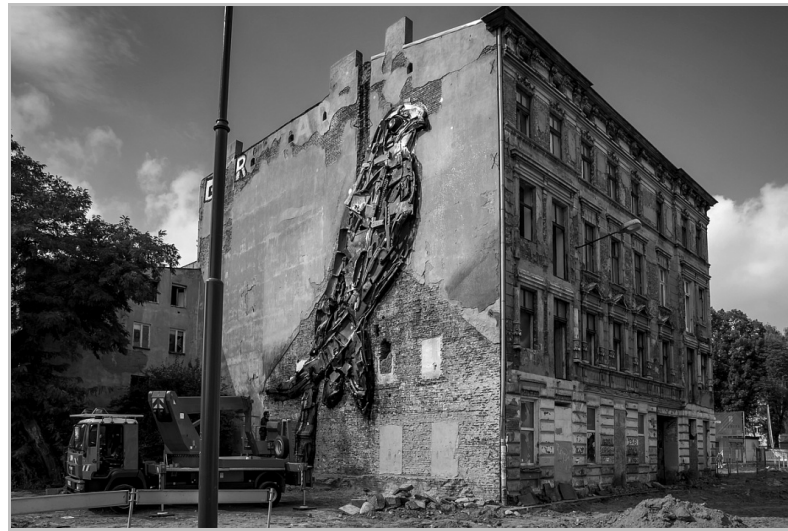

Fot. 7. Mural/instalacja na ścianie szczytowej kamienicy do generalnego remontu wykonana z materiałów pochodzących $\mathrm{z}$ recyclingu i kolorowych farb - autor: Artur Bordalo - Bordalo II (Portugalia) (fot. I. Jażdżewska)

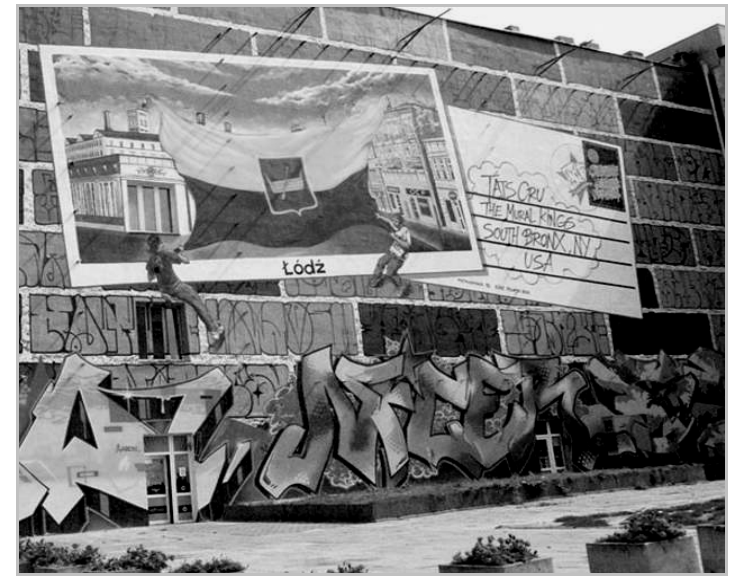

Fot. 8. Jeden z pierwszych murali wielkoformatowych w Łodzi wykonany przez "grafficiarzy” z nowojorskiej grupy Tats Cru Źródło: http:/ / warszawa.naszemiasto.pl

Ostatnie wielkoformatowe graffiti, nawiązujące do historii miasta, przedstawia wybitnego pianistę, łodzianina - Artura Rubinsteina, który został namalowany przez brazylijskiego artystę - E. Kobrę (fot. 9).

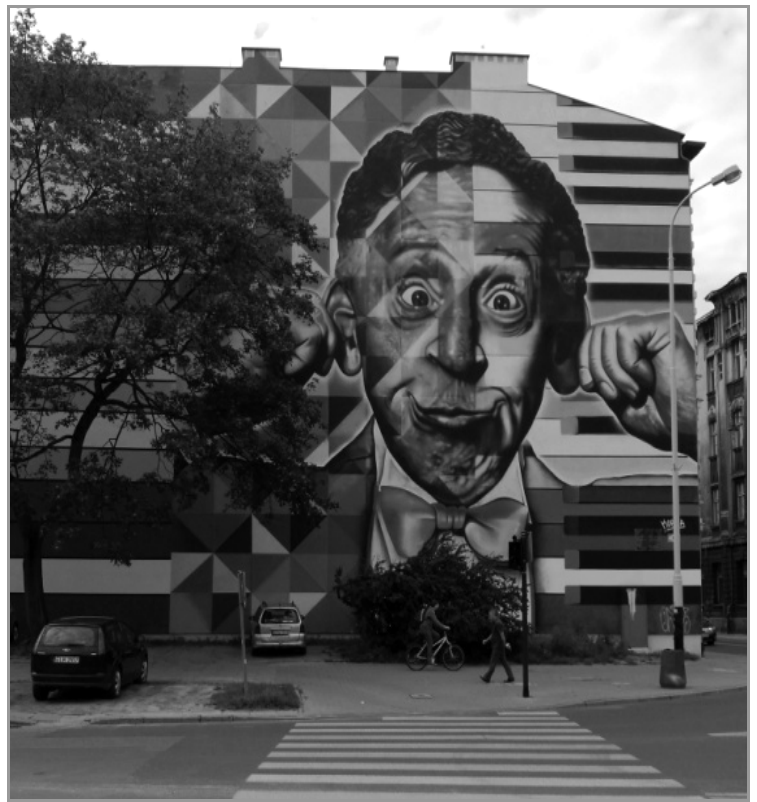

Fot. 9. Mural wielkoformatowy przedstawiający urodzonego w Łodzi pianistę Artura Rubinsteina - autor: E. Kobra (Brazylia) (fot. I. Jażdżewska)

Tab. 1. Kraj pochodzenia artystów realizujących murale w Łodzi w latach 2002-2016

\begin{tabular}{|c|c|c|c|c|}
\hline \multirow[t]{2}{*}{ Lp. } & \multirow[t]{2}{*}{ Kraj } & \multicolumn{2}{|c|}{$\begin{array}{l}\text { Artyści/zespół } \\
\text { artystów }\end{array}$} & \multirow{2}{*}{$\begin{array}{c}\text { Nazwiska lub } \\
\text { pseudonimy, } \\
\text { ew. aka }\end{array}$} \\
\hline & & liczba & $\%$ & \\
\hline 1 & Australia & 2 & 3,3 & Shida, Stormi Milles \\
\hline 2 & Belgia & 1 & 1,6 & Roa \\
\hline 3 & Brazylia & 3 & 4,9 & $\begin{array}{l}\text { Eduardo Kobra, Nunca, Os } \\
\text { Gemeos }\end{array}$ \\
\hline 4 & Chile & 1 & 1,6 & Inti \\
\hline 5 & Chiny & 2 & 3,3 & Daleast, Messy Desk \\
\hline 6 & Francja & 3 & 4,9 & $\begin{array}{l}\text { 3ttman, Remed, } \\
\text { Zoe\&Velvet }\end{array}$ \\
\hline 7 & Hiszpania & 6 & 9,8 & $\begin{array}{l}\text { Aryz, Borondo, Boa } \\
\text { Mistura, Kenor, Manolo } \\
\text { Mesa }\end{array}$ \\
\hline 8 & Izrael & 3 & 4,9 & Dede, Nunca, Untay \\
\hline 9 & Niemcy & 2 & 3,3 & Sat One, Brenna Urban \\
\hline 10 & Polska & 28 & 45,9 & Wykaz autorów poniżeja \\
\hline 11 & Portugalia & 2 & 3,3 & Vhils, Bordalo II \\
\hline 12 & Puerto Rico & 1 & 1,6 & Alexis Diaz \\
\hline 13 & Rosja & 1 & 1,6 & Morik \\
\hline 14 & USA & 3 & 4,9 & Tats Cru, Gaia, \\
\hline 15 & Włochy & 3 & 4,9 & $\begin{array}{l}\text { Opiemme, Cactud \& } \\
\text { Maria, Agostino Lacurci }\end{array}$ \\
\hline \multicolumn{2}{|c|}{ Razem } & 61 & 100,0 & $\mathrm{x}$ \\
\hline
\end{tabular}

a Wykaz polskich autorów murali w Łodzi: Aleksandra Adamczuk, Andrzej PoProstu, Axl Studio, Łukasz Berger, Bezt, Maciej Blaźniak, Katarzyna Bogucka, Chazme, Ciach Ciach, Etam Crew, Gregor Gonsior aka Bombalino, Jadwiga Hardt, Konrad Koch, Krik, Lump, Massmix, Meisal/Meisallasiem - Sławomir Krysiak, M-City, Paulina Nawrot, Pener, Maciej Pisiałek, Proembrion, Mikołaj Rejs, Raspazjan, Sainer, Sepe, Karolina Tłuczek, Tone, Zbiok.

Źródło: opracowanie własne. 


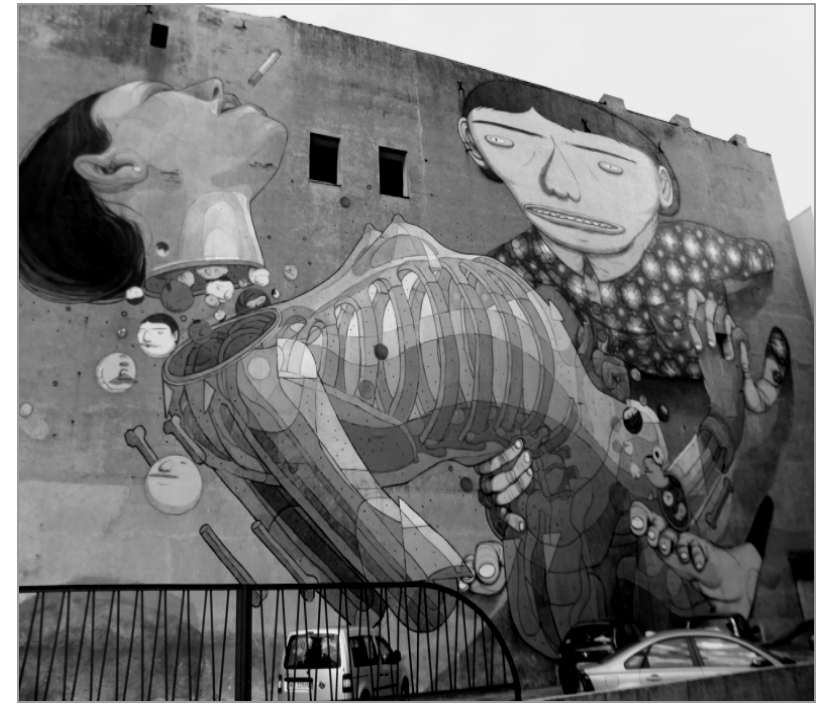

Fot. 10. Mural Os Gemoes (Brazylia) i Aryz (Hiszpania) (fot. D. Chraścik, 2016)

Autorami łódzkich murali byli artyści z 15 krajów (tab. 1). Reprezentowali oni prawie wszystkie kontynenty. Niektóre prace były autorstwa kilku artystów z różnych krajów, np. brazylijskich bliźniaków - Os Gemeos i Hiszpana - Aryz (fot. 10) lub jednego (fot. 11).

\section{6. ŁÓDZKIE MURALE W OPINII UCZESTNIKÓW WYCIECZEK ${ }^{4}$}

Od stycznia do grudnia 2014 r. Galeria Urban Forms zrealizowała 10 wycieczek dostępnych dla wszystkich chętnych. Informacje o nich $\mathrm{w}$ języku polskim pojawiały się zazwyczaj na tydzień przed wydarzeniem na stronie internetowej oraz na oficjalnym profilu Facebook Fundacji Urban Forms (www.facebook.com/ urbanforms/ oraz www.urbanforms.org). Prowadzone były w języku polskim. Mogło w nich uczestniczyć maksymalnie 150 osób (minimalna liczba 30). Aby wziąć w niej udział należało stawić się na wyznaczone miejsce zbiórki o danej godzinie. Część wycieczek była płatna, zdarzały się również darmowe (tab. 2).

Zwiedzanie trwało zazwyczaj około trzech godzin, trasa nie była $z$ góry podana, opracowywał ją przewodnik, który wskazywał miejsce zbiórki uczestników. Wycieczki zorganizowane we wrześniu odbywały się z wykorzystaniem autokarów turystycznych, które mogły pomieścić około 55 osób, pozostałe autobusami miejskimi wynajętymi od Miejskiego Przedsiębiorstwa Komunikacyjnego $\mathrm{w}$ Łodzi. W jednym autobusie możliwe było więc pomieszczenie grup ponadstuosobowych; niestety odbywało się to kosztem komfortu podróży z powodu małej liczby miejsc sie-

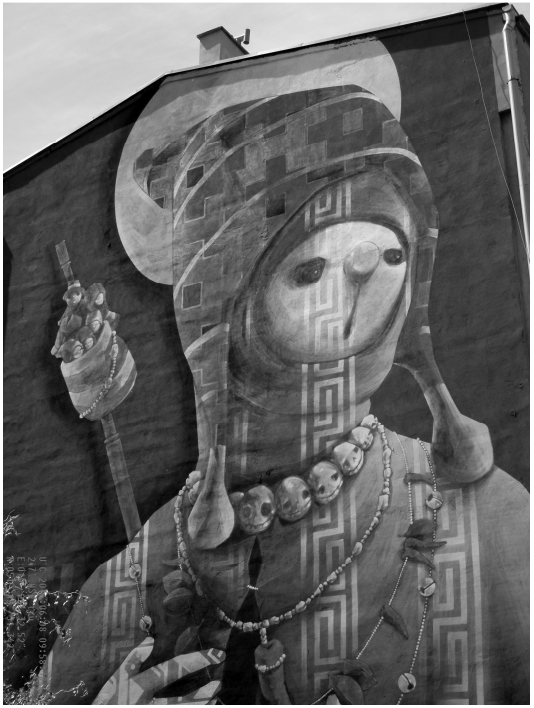

Fot. 11. Inti (Chile) - Holly Warrior (fot. I. Jażdżewska)

dzących. Kolejną zaletą korzystania z autobusów wypożyczonych $\mathrm{z}$ MPK była możliwość uprawnionego zatrzymywania się na przystankach komunikacji miejskiej. Większość trasy pokonywało się autobusem. Jeżeli jednak prace artystów były od siebie niewiele oddalone grupa pokonywała odcinek pieszo. Gdy uczestnicy przechodzili jakiś odcinek pieszo, autokar przemieszczał się na miejsce ustalone wcześniej z przewodnikiem.

Ankietowani byli wyłącznie uczestnicy wycieczek ogólnodostępnych. Odpowiedzi na zadane w kwestionariuszu pytania udzieliło 762 uczestników, co stanowiło $78 \%$ wszystkich korzystających (983 osoby) z 10 zorganizowanych w 2014 r. wycieczek. Można zatem uznać, że badania były reprezentatywne.

Tab. 2. Wycieczki oraganizowane przez Galerię Urban Forms w 2014 r.

\begin{tabular}{|c|c|c|c|c|}
\hline Data & $\begin{array}{c}\text { Liczba } \\
\text { uczestni- } \\
\text { ków }\end{array}$ & $\begin{array}{c}\text { Liczba } \\
\text { ankieto- } \\
\text { wanych }\end{array}$ & $\begin{array}{c}\text { Wydarzenie } \\
\text { towarzyszące }\end{array}$ & $\begin{array}{c}\text { Koszt } \\
\text { (zt) }\end{array}$ \\
\hline 12.01. & 81 & 75 & brak & 18 \\
\hline 22.02. & 124 & 101 & Targi Turystyczne & $18^{\mathrm{a}}$ \\
\hline 30.03. & 122 & 122 & brak & 18 \\
\hline 27.04. & 118 & 118 & brak & 18 \\
\hline 17.05. & 135 & 135 & Noc Muzeów & 0 \\
\hline 25.05. & 120 & 120 & brak & 18 \\
\hline 26.07. & 108 & 108 & Urodziny Łodzi & 0 \\
\hline 20.09. & 55 & 55 & Festiwal Urban Forms & 0 \\
\hline 27.09. & 53 & 53 & Festiwal Urban Forms & 0 \\
\hline 29.11. & 67 & 67 & brak & 18 \\
\hline $\mathrm{x}$ & 983 & 762 & $\mathrm{x}$ & $\mathrm{x}$ \\
\hline
\end{tabular}

a Dla osób z biletem z targów wycieczka była bezpłatna. Źródło: opracowanie własne. 
Wśród uczestników wycieczek więcej było kobiet, które stanowiły 58\% grupy ankietowanych (mężczyźni $42 \%$ ). Osoby pełnoletnie biorące w nich udział były w różnym wieku. Najliczniejszą grupą byli uczestnicy w przedziale wiekowym 21-30 lat - 180 mężczyzn i 179 kobiet; w sumie 359 osób, czyli 47\% wszystkich ankietowanych. Drugą pod względem wielkości grupą była młodzież w wieku od 18 do 20 lat. Na grupę tę składało się 131 osób (66 mężczyzn i 65 kobiet) - 17\% badanych. W sumie uczestnicy w wieku 30 lat i mniej stanowili 70\% wszystkich biorących udział w wycieczkach. Można stwierdzić więc, że dominowali w nich ludzie młodzi. Ciekawe są dane, które wskazują również na zainteresowanie tematem sztuki ulicznej osób powyżej 50. roku życia. Spośród ankietowanych 90 osób zaznaczyło przedział wiekowy >50 lat, w tym 68 ankietowanych stanowiły kobiety, a 22 mężczyźni. Może to świadczyć o tym, że temat street artu, który powiązany jest $z$ kulturą hip-hopu, wzbudza zainteresowanie również osób dojrzałych i starszych.

Większość uczestników (68\%) stwierdziła, że głównym źródłem informacji o wycieczce była strona Facebooka, 23\% ankietowanych zadeklarowało, że o wycieczce dowiedziało się od osoby trzeciej, a pozostali z prasy, radia, telewizji i strony internetowej Galerii. Prawie wszyscy (97\%) byli po raz pierwszy tutaj na wycieczce. Na pytanie: „Jak ocenia Pan/Pani wycieczkę szlakiem murali Galerii Urban Forms?", 54\% osób odpowiedziało, że bardzo dobrze, 28\% dobrze, $4 \%$ ankietowanych źle ją oceniło, a $14 \%$ nie miało zdania w tej kwestii.

Dość zaskakujące były odpowiedzi na pytanie "Czy interesuje się Pan/Pani street artem?", gdyż 57\% ankietowanych zadeklarowało, że interesuje się, ale aż $43 \%$ w kwestionariuszu stwierdziło, że nie. Może to oznaczać, że szukali oni po prostu ciekawej formy spędzenia czasu wolnego w weekend.

Aby poznać zasięg przestrzenny miejsca zamieszkania uczestników wycieczek, pierwsze pytanie zadano pod tym kątem i było to: "Czy jest Pan/Pani mieszkańcem Łodzi”. 63\% respondentów była łodzianami, a $37 \%$ stanowili ankietowani spoza Łodzi. Wielu z nich przyjechało z miast aglomeracji łódzkiej lub innych miejscowości województwa łódzkiego. Z odpowiedzi udzielonej przez respondentów wywnioskować można, że skoro aż 90\% uczestników mieszka w województwie łódzkim, to ruch turystyczny generowany podczas tych wycieczek ma charakter regionalny.

Osoby przyjezdne zostały poproszono o udzielenie odpowiedzi na pytanie: „Na jak długo planuje Pan/ Pani pobyt w Łodzi?". Ponad połowa respondentów (58\%) zadeklarowała tylko kilkugodzinny pobyt w Łodzi z uczestnictwem w wycieczce. Drugą z kolei liczną grupę (26\%) stanowiły osoby, które zadeklarowały pobyt od jednego do trzech dni. Pozostający w Łodzi do siedmiu dni to $14 \%$ ankietowanych. Najmniejszą grupą (2\%) byli turyści pozostający ponad siedem dni. Wyraźnie widać zależność między długością pobytu w mieście a głównym powodem przyjazdu do niego. Ankietowani, których wycieczka była głównym motywem przyjazdu, przybywali do miasta tylko na kilka godzin $(42,4 \%)$ lub do trzech dni $(17,1 \%)$ (tab. 3).

Tab. 3. Zależność między długością trwania pobytu a głównym powodem przyjazdu uczestników wycieczek Galerii Urban Forms w Łodzi w 2014 r.

\begin{tabular}{|l|c|c|c|}
\hline \multirow{2}{*}{\begin{tabular}{c}
\multirow{2}{*}{$\begin{array}{c}\text { Długość } \\
\text { pobytu } \\
\text { w Łodzi }\end{array}$} \\
\cline { 2 - 4 }
\end{tabular}} & \multicolumn{3}{|c|}{$\begin{array}{c}\text { Odsetek odpowiedzi na pytanie: } \\
\text { "Czy wycieczka była głównym powodem } \\
\text { przyjazdu?" }(n=280)\end{array}$} \\
\cline { 2 - 4 } & tak & nie & $\begin{array}{c}\text { była jednym } \\
\text { z celów przyjazdu }\end{array}$ \\
\hline Kilka godzin & 41,4 & 7,9 & 9,3 \\
\hline $1-3$ dni & 17,1 & 5,4 & 3,2 \\
\hline $4-7$ dni & 7,1 & 3,9 & 2,9 \\
\hline$>7$ dni & 0,7 & 0,4 & 0,7 \\
\hline
\end{tabular}

Źródło: opracowanie własne.

Na pytanie otwarte: „Jakie inne atrakcje turystyczne planuje Pan/Pani odwiedzić w czasie swojego pobytu w Łodzi?" udzielono 374 odpowiedzi na 280 wypełnionych ankiet. 38 ankietowanych pozostawiło to pytanie bez odpowiedzi, a pozostali wskazwali kilka atrakcji turystycznych. Najczęściej wymienianymi miejscami przez respondentów były Manufaktura (37\%), ulica Piotrkowska (30\%) Muzeum Animacji Se-Ma-For (7\%) i Muzeum Historii Miasta Łodzi (6\%). Nie są to miejsca związane z łódzkimi muralami, ale znane jako atrakcje turystyczne Łodzi.

Ciekawa była odpowiedź wszystkich respondentów uczestników wycieczek na pytanie: „Czy uważa Pan/Pani, że wielkoformatowe murale mogą stać się wizytówką Łodzi?". Większość (64\%) z nich odpowiedziało na nie twierdząco, ale $36 \%$ udzieliło odpowiedzi negatywnej i nie widziało w łódzkich muralach potencjału turystycznego i marketingowego.

Wyniki badań wśród uczestników wycieczek można porównać w wynikami raportu z badań jakościowych autorstwa A. GRALIŃSKIEJ-TOBOREK i W. KAZIMIERSKIEJ-JERZYK (2014) pt. Experience of Art in Urban Space Urban Forms Gallery 2011-2013. Autorki przebadały pod tym kątem 454 osoby, które znajdowały się w pobliżu 29 murali, a sposób doboru próby badawczej był przypadkowy. Na zadanie pytanie: „Komu potrzebne są murale?", ankietowani najczęściej mówili bardzo ogólnie: wszystkim (176), młodzieży, ludziom młodym (128), łodzianom/mieszkańcom, miastu (jako jego mieszkańcom - 119), na trzecim miejscu wymienili oni turystów (99). Pozostałe wskazania były mniej liczne i były to: miastu jako przestrzeni fizycznej (34), artystom (32), wszystkim zainteresowanym - zależnie od wrażliwości (25), starszym (11), władzy (10). Autor- 
ki raportu zainteresowane były również odpowiedziami respondentów na pytanie, czy murale są sztuką. Wyniki badań wskazały, że 440 osób zaklasyfikowało wielkoformatowe graffiti jako sztukę, z czego aż 409 osób odbierało ją pozytywnie, przy czym respondenci nie dokonywali podziału na sztukę wysoką i niską, nie posługiwali się też pojęciem sztuki popularnej.

\section{7. ŁÓDZKIE MURALE W PRZESTRZENI WWW}

Informacje o łódzkich muralach znajdują się w wielu miejscach w Internecie. Można je podzielić na:

- relacje, wspomnienia zarejestrowane i udostępnione na YouTube;

- informacje w mediach lokalnych i krajowych;

- informacje w mediach zagranicznych;

- informacje i prezentacje na stronach autorów (blogi, galerie);

- informacje i prezentacje na stronach turystów i miłośników sztuki ulicznej (blogi, galerie).

W celu poznania zasięgu przestrzennego oddziaływania łódzkich murali analizie poddane zostały media zagraniczne lub polskie, ale nieprowadzone w języku polskim.

Jedne z pierwszych relacji o łódzkich muralach zostały umieszczone na YouTube w 2008 r. i dotyczyły Meeting of Styles z 2002 r. Również następne edycje Meeting of Styles publikowały w Internecie informacje o ich organizacji w Łodzi. Ale dopiero kampania reklamowa, która miała miejsce gdy namalowano pierwszych sześć murali wielkoformatowych w ramach festiwalu Galerii Urban Forms jesienią 2011 r., spowodowała, że informacja o nich pojawiała się w lokalnej, krajowej i zagranicznej prasie, radiu i telewizji, niekiedy jeszcze przed ich realizacją (http://www. expressilustrowany.pl/...).

Informacje o realizowanych muralach pojawiają się również na blogach i w fotogaleriach autorów murali, których ponad połowa pochodziła spoza Polski. Reprezentowali oni 14 krajów z różnych kontynentów (tab. 3). Osoby interesujące się sztuką uliczną mogą w nich zazwyczaj znaleźć informację o lokalizacji poszczególnych projektów, co może być inspiracją do ich obejrzenia $\mathrm{w}$ naturalnych warunkach w Łodzi, gdzie widać otaczającą je zabudowę (https://www.google. $\operatorname{com} / . .$.$) .$

Oprócz fotogalerii autorów łódzkie murale można oglądać również na blogach i w fotowspomnieniach z podróży. Czasami umieszczane są w nich tylko fotografie, ale niekiedy też krótki komentarz (np. http:/ / blog. globalstreetart.com/, https:/ / newzar.wordpress. com/, http://www.businessinsider.com/, http:// www.dirtycarsmillioncows.com/). Ich opinie są zwyk- le pozytywne i dzięki temu zachęcają do odwiedzenia Łodzi. Osobnym miejscem są publikacje fotografii, np. Flicker, Pinterest, Instagram, na których miłośnicy murali dzielą się swoimi fotografiami z innymi.

Magazyny internetowe poświęcone sztuce ulicznej i sztuce współczesnej wspominają o łódzkich muralach kilkakrotnie od 2011 r., na takich stronach jak np.: http://graffuturism.com/, http://www.brooklyn streetart.com/, https://streetartnews.net/, http:/ / urbanshit.de/, http://streetartunitedstates.com/, http://ilgorgo.com/, http://www.juxtapoz.com/, http:/ / www.graffitiartmagazine.com/, http://www. streetartutopia.com/, http://www.cubebreaker.com/, https://streetartnews.net/, http://www.journal-dudesign.fr/, http://www.isupportstreetart.com/, http:// verynearlyalmost.com/, https://www.weheart.com/, http://www.fatcap.com/. W roku 2014 w magazynie http://mentalfloss.com/sugerowano umieszczenie na trasie światowego street artu 11 miast, wśród których wymieniono Łódź. Również na portalach prezentujących atrakcyjne miejsca na świecie można napotkać informacje o łódzkich muralach, np. http:/ / www.amusingplanet.com/, http://twisted sifter.com/. Portal Earthporm stawia łódzkie murale na piątym miejscu po Meksyku, Londynie, Pradze i Lizbonie wśród 20 Of The Best Cities To See Street Art.

Tytuły artykułów wprowadzają czytelnika nie tylko w świat łódzkich grafitti wielkoformatowych, ale również w szerszy kontekst odbioru miasta. W wydawanym w 18 krajach The Huffington Post w 2012 r. Jaime Rojo \& Steven Harrington Co-Founders, BrooklynStreetArt.com tak pisali o łódzkich muralach:

Wielkie Murale Sztuki Ulicznej zmieniają polskie miasto Łódź" - Miasto Łódź w Polsce promuje pracę artystów ulicznych z całego świata jako sposób kreowania kulturalnego ożywienia miasta, którego populacja wynosi trzy czwarte miliona ${ }^{5}$.

Rok później w CNN, w zakładce Travel w artykule pt. "Bigger than Banksy: Polishstreet art goeslarge” (http:/ / edition.cnn.com), zaprezentowano łódzkie murale szerokiemu odbiorcy. Po nim pojawiały się następne w The Huffington Post a Tidal Wave of Lodz Reborn: 'Lodz Murals' Distinguishes a Polish City (http:// www.huffingtonpost.com/jaime-rojo-steven-harring ton/a-tidal ...) Przytaczają w nim opinię Michała Bieżyńskiego:

Założyciel Galerii Form Miejskich mówi, że ma wizję stworzenia takiego samego ikonicznego wizerunku Łodzi z muralami, jaki prezentuje Paryż ze swoją wieżą Eiffla: 'Chciałbym, aby ludzie w skali globalnej myśleli o Łodzi jako mieście o wyjątkowej sztuce publicznej', mówi z powagą, przyznając jednocześnie, że sztuka publiczna błyszczy również w wielu innych miastach. Gdy myślisz o sztuce publicznej, jednym z pierwszych miejsc, które ujrzysz swym wewnętrznym okiem jest Łódź. Porównywanie projektu 
muralowego do jednej z najważniejszych "perełek” architektury wspólczesnej to oczywista przesada, ale chciałbym stworzyć tego typu mechanizm, tego typu skojarzenie ${ }^{6}$.

W http://www.boredpanda.com/ łódzki mural autorstwa EtamCrew był na 17. miejscu wśród „30 Amazing Large Scale Street Art Murals From Around The World". W roku 2014 mural artysty DA Least znalazł się na liście The 60 Best Street Art Works of 2014 ogłoszonej przez http:/ / www.artfido.com.

W 2015 r. w wydaniach koreańskim, francuskim, maghrebu, hiszpańskim i amerykańskim The Huffington Post Katherine Brooks wskazuje Łódź jako jedno z "17 mniej znanych miast, które powinieneś odwiedzić, by zobaczyć sztukę uliczną" (http://www. huffington post.com/entry/...). Również brytyjski „Telegraph” w 2016 r. zachęca do odwiedzenia miasta. Jonathan Thompson napisał (http://www.telegraph. co.uk/):

Łódź - bajkowe miasto, którego nie sposób wyrazić" jeśli chodzi o bajkowe miejscowości, polskie miasto Łódź nie znalazłoby się na liście miejsc do zobaczenia przed śmiercią u zbyt wielu osób - jeśli w ogóle u kogoś. Nazywana „Manchesterem Polski”, w XIX wieku, Łódź była zadymionym, przemysłowym potworem, zanim popadła $\mathrm{w}$ katastrofalną ruinę po Wielkim Kryzysie. Ale dziś pisze się, a raczej maluje epickie baśnie. Gdy wędrujemy przez miasto - trzecie największe w Polsce, po Warszawie i Krakowie - naszym oczom ukazują się ogromne, kolorowe murale umieszczone na ścianach zniszczonych kamienic, magazynów i fabryk. Jest ich coraz więcej. Wiele tych przykuwających uwagę dzieł sztuki to ogromne, tchnące energia interpretacje tradycyjnych polskich opowieści. Jedno z najbardziej imponujących, „Stara kobieta z kurczakiem", wznosi się ponad jednym z większych skrzyżowań, ilustrując znany wiersz dla dzieci, w którym sympatyczna babcia i jej złotopióra kura lecą na księżyc ${ }^{7}$.

Kilka dni później miasto promowane było na stronie Archidiecezji Westminster (http:/ / dowym.com/):

Artyści uliczni z całego świata pozostawili po sobie znaki i murale na ścianach Łodzi. Idąc przez miasto, na pewno zobaczysz ich sporo, a jeśli chcesz je uchwycić wszystkie, po prostu ściągnij z Internetu mapę 8 .

Pojedyncze artykuły można znaleźć na stronach: tureckich, np. http://allmagnews.com/lodz-murals/, meksykańskich - http://graffitiworld.tv/, włoskich - http://arte.sky.it/ i http://www.art-vibes.com/, duńskich - http://forfhdm.polennu.dk/.

Trudno ocenić zasięg przestrzenny oddziaływania prezentowanych powyżej mediów internetowych. Można jedynie stwierdzić, że najwięcej informacji i fotografii łódzkich murali było w mediach USA, następnie brytyjskich, francuskich, niemieckich i włos- kich. Dominował w nich język angielski, a niemiecki, włoski, francuski, hiszpański były w mniejszości. Przeszukiwano witryny internetowe używając alfabetu łacińskiego, dlatego nie można stwierdzić, czy tagi \#lodz, \#mural występowały w innych alfabetach (cyrylica, chiński, arabski $\mathrm{i}$ in.).

\section{PODSUMOWANIE}

Łódzkie murale nie mają tak bogatej historii jak spotykane w miastach amerykańskich, takich jak np. Filadelfia, gdzie już od lat 80 . XX w. stały się atrakcją miasta włączoną do jego oferty turystycznej. Ich pojawienie się w Łodzi kilkadziesiąt lat później niż w miastach amerykańskich, na początku XXI w., i ich rozwój ma jednak podobne korzenie, nawiązujące do hip-hopu i sztuki ulicznej. Stało się to możliwe dopiero po transformacji ustrojowej, gdyż w okresie socjalizmu murale wielkoformatowe realizowane były jedynie na zlecenie władz lub przedsiębiorstw państwowych.

Graffiti wielkoformatowe na ścianach budynków Łodzi są rozpoznawalne wśród coraz szerszej grupy miłośników steet artu w Polsce i na świecie. Świadczą o tym wzmianki w mediach społecznościowych, takich jak blogi podróżników i artystów, Facebook, Instagram, Pinterst, Flicker, You Tube i innych, a także doniesienia prasowe $\mathrm{w}$ mediach na całym świecie. Pochodzenie dużej grupy artystów wykonujących swoje prace na ścianach łódzkich budynków, którzy reprezentują prawie wszystkie kontynenty, unaoczniają zasięg przestrzenny znajomości miasta jako „przyjaznego" muralom (tab. 1). Niewiele $z$ nich nawiązuje do historii miasta oraz znanych w Polsce i na świecie jego mieszkańców, co mogłoby w większym stopniu wpłynąć na jego rozpoznawalność.

Poznanie opinii uczestników wycieczek trasą łódzkich murali, organizowanych w 2014 r. przez Galerię Urban Forms, pozwoliło na ukazanie przestrzennego zasięgu ich oddziaływania oraz ewentualnego zasięgu przyciągania przez nie turystów. Wyniki przeprowadzonych badań wykazały, że organizowane przez fundację Urban Forms wycieczki w języku polskim są wybierane głównie przez mieszkańców Łodzi i najbliższych miejscowości, co sugeruje, że nie mają one jednak zasięgu krajowego i tym bardziej międzynarodowego. Miasto nie przygotowało jeszcze oferty zwiedzania wielkoformatowych graffiti dla turystów zagranicznych (w innych językach). Należy mieć nadzieję, że to się zmieni, gdyż istnieje duża grupa miłośników tej sztuki na świecie, o czym świadczą relacje z podróży na blogach turystycznych. Wówczas zasięg oddziaływania łódzkich murali, których z roku 
na rok jest coraz więcej, powinien wzrosnąć wśród potencjalnych turystów, choć trudno przewidzieć, w jakim stopniu.

Należy zgodzić się z C. GRODACHEM (2009), że przestrzenie artystyczne, w szczególności street artu, moga odgrywać różne role w przestrzeni publicznej. Jedną z nich może być przyciągnięcie turystów do miasta, którzy generowaliby wydatki w Łodzi. Z badań tego autora wynika jednak, że potencjał ten jest zmarnowany, ponieważ obiekty nie znajdują się w bliskiej fizycznej odległości od placówek handlowych. W Łodzi ten aspekt nie był zbadany, więc należałoby go podjać, wzorem R. KOSTERA i J. RANDALLA (2005), w dalszych badaniach naukowych.

\section{PRZYPISY}

1 Film nominowano do Oscara w 1974 r., a reżyserowi w 2000 r. przyznano honorowego Oscara.

${ }^{2}$ W której studiowali m.in. Roman Polański, Jerzy Skolimowski, Zbigniew Rybczyński, Krzysztof Zanussi, Krzysztof Kieślowski oraz operator Witold Sobociński.

3 "This is a wicked city with a very activescene. If you go through it, you find a lot of greyish walls, nice old architecture, in a bad status - very demolished - and a lot lot of bombings, tags and throw-ups" (http:/ / www.meetingofstyles. com/blog).

${ }^{4}$ Rozdział 6 powstał na podstawie D. CHRAŚCIK (2016).

5 "Huge Street Art Murals Transform City Of Lodz In Poland" - The city of Lodz in Poland is promoting the work of street artists from around the world as a way of creating a cultural reinvigoration of this city whose population is three quarters of a million ((http:/) www. huffingtonpost.com/jaime-rojo-steven-harrington/large).

6 "Founder of Gallery Urban Forms says that his vision is to create the same sort of iconic image of Lodz with murals as Paris with the Eiffel Tower: "I would like that people on the global scale would think of Lodz as a city with exceptional public art," he says grandly while acknowledging that public art shines in many other cities as well. "When you are thinking about public art, one of the first places that you will see in your mind's eye is Lodz. Of course, comparing the mural project to the one of the most important "pearls" of modern architecture is pure overstatement, but I would like to create this type of mechanism, this type of association." (http://www.huffington post.com/jaime-rojo-steven-harrington/a-tidal ...).

7 "Eódz: the fairy tale city you can't pronounce" when it comes to fairy tale destinations, the Polish city of Łódź wouldn't trouble many - if any - bucket lists. Nicknamed "the Manchester of Poland", it was a smoking industrial behemoth during the $19^{\text {th }}$ Century, before collapsing into catastrophic decline after the Great Depression. But fairy tales are writ large here today - or rather, painted large. Across the city - Poland's third largest after Warsaw and Krakow - colossal, colourful murals are appearing on the walls of derelict apartment blocks, warehouses and factories in ever-growing numbers. And many of these arresting pieces of art are enormous, ebullient interpretations of traditional Polish tales. One of the most impressive, "The Old Lady With The Chicken", towers over a major junction, depicting a famous children's poem where an amiable grandma and her gold-feathered hen fly to the moon." (http:/ / www .tele graph.co.uk/).

8 "Street artists from all over the world have left their marks and murals on the walls of Łódz. Just walking around the city you're sure to see a good number of them, and if you want to catch'em all just download the map" ((http://dowym.com/).

\section{BIBLIOGRAFIA}

ARREOlA D., 1984, Mexican American exterior murals, "Geographical Review", 74(4), s. 409-424, DOI: 10.2307/215024.

CHRAŚCIK D., 2016, Ruch turystyczny w Łodzi na przykładzie wycieczek szlakami Galerii Urban Forms, mps pracy magisterskiej pod kier. I. Jażdżewskiej, w IGMIT UŁ, Łódź.

DICKINSON J., 2012, From graffiti to murals and back again: Philadelphia's spectacular streetscape, „Visualidades”, Goiânia, 10, 1, s. 63-79.

GRALIŃSKA-TOBOREK A., KAZIMIERSKA-JERZYK W., 2014, Experience of art in urban space Urban Forms Gallery 2011-2013, Urban Forms Foundation, Łódź.

GRODACH C., 2009, Art spaces, public space, and the link to community development, "Community Development Journal", 45(4), s. 474-493.

GRUBER Ch.J., 2008, The message on the wall: Mural arts in postrevolutionary Iran, „Persica”, 22, s. 15-46, DOI: 10.2143/PERS. 22.0. 2034399.

KOSTER R.L.P., 2008, Mural-based tourism as a strategy for rural community economic development. Advances in culture, "Tourism and Hospitality Research", 2, s. 153-292, http:// dx.doi.org/10.1016/s1871-3173(08)02004-1.

KOSTER R., RANDALL J., 2005, Indicators of community economic development through mural-based tourism, "Canadian Geographer", 49, s. 42-60.

KOTER M., 1990, The morphological evolution of a nineteenth-century city centre: Lodz, Poland, 1825-1973, [w:] The built form of western cities: essays for MRG Conzen on the occasion of his eightieth birthday, TR Slater, Leicester University Press, s. 109141.

KOZINETS R.V., 2002, The feld behind the screen: Using netnography for marketing research in online communities, "Journal of Marketing Research", 39 (February), s. 61-72.

KOZINETS R.V., 2012, Netnografia. Badania etnograficzne online, Wyd. Naukowe PWN, Warszawa.

LARKIN C., 2014, Jerusalem's separation wall and global message board: Graffiti, murals, and the art of Sumud, "Arab Studies Journal", 22(1).

MOKRAS-GRABOWSKA, J., 2014, Art-tourism space in Łódź: The example of the Urban Forms Gallery/ Przestrzen turystyczno-artystyczna Łodzi na przykładzie Galerii Urban Forms, „Tourism/ Turyzm", 24(2), s. 23-30/pp. 25-33, DOI: 10.2478/ tour-2014-0013.

SAPEGA E.W., 2002, Image and counter-image: The place of Salazarist images of national identity in contemporary Portuguese visual culture, „Portuguese Cultural Studies”, 39, 2, s. 45-64.

SIEBER T., CORDEIRO G.Í., FERRO L., 2012, The neighbourhood strikes back: Community murals by youth in Boston's communities of colour, „City \& Society”, 24, 3, s. 263-280, DOI: 10.1111/ciso. 12000.

STĘPIEŃ B., 2010, Łódzkie murale. Niedoceniona grafika użytkowa PRL-u, Wyd. Księży Młyn, Łódź.

ŚWIEŚCIAK M., MATULEWSKI P., MAKOHONIENKo M., 2015, Turystyka graffiti $w$ opinii respondentów $z$ wybranych miast: Gdańsk, Łódź, Poznań, "Turystyka Kulturowa”, 8, s. 41-56.

YOUNG, A., 2010, Negotiated consent or zero tolerance? Responding to graffiti and street art in Melbourne, "City", 14(1-2), s. 99114.

Wight E., 2006, Making "Mexican-ness" in Pilsen: Perspectives on the meaning of cultural production in cty space, paper presented at the 2006 Annual Meeting of the American Sociological Association, Montreal, August 12. 
http:/ / chazme718.blogspot.com/2014/10/recycles-diptych-toneproembrion-sepe.html.

http://dowym.com/voices/lodz-city-surprises/.

http:/ / edition.cnn.com/2013/11/11/travel/bigger-than-banksy -polish-street-art-goes-large/.

http:/ / warszawa.naszemiasto.pl/artykul/551664,pocztowko wy-mural-po-amerykansku-tats-cru-malowali-na-ul,id,t. html; 2013.

http:/ / www.expressilustrowany.pl/artykul/870521,kolorowan ie-srodmiescia-mistrzowie-stworza-murale,id,t.html.

http:/ / www.galeriaurbanforms.org.

http:/ / www.huffingtonpost.com/entry/lesser-known-streetart-cities_us_5667328de4b079b281907174.

http:/ / www.huffingtonpost.com/jaime-rojo-steven-harrington /a-tidal-wave-of-lodz-rebo_b_8389740.html.

http:/ / www.huffingtonpost.com/jaime-rojo-steven-harrington /large-murals-transform-lodz_b_3428241.html.

http://www.meetingofstyles.com/. http:/ / www.meetingofstyles.com/blog/22-24-july-2005-lodz-po land/.

http://www.meetingofstyles.com/blog/lodz-poland/.

http://www.murale.mnc.pl/i/mu_eng.pdf.

http://www.telegraph.co.uk/travel/destinations/europe/articl es/europe-forgotten-fairy-tale-cities/.

http://www.urbanforms.org/about/en/.

https://www.google.com/culturalinstitute/beta/u/0/exhibit/ AQN6U_wQ?hl=pl.

https://www.muralarts.org/tours/.

https:/ / www.youtube.com/watch?v=rMf_WL-mPf0.

www.en.lyon-france.com/Press-Professional/News/A-new-

iPhone-application-to-find-the-painted-walls-murals.

www.expressilustrowany.pl/artykul/835907,murale-wizytowka

-lodzi-najwiekszy-na-swiecie-jest-na-piotrkowskiej,id,t.html; 20.06.2015.

www.lodz.wyborcza.pl/lodz/1,107545,8217920,Murale_na_Piot

rkowskiej_Czy_to_dobre_miejsce_na_street.html; 20.06.2015. www.murale.mnc.pl/o_023.htm; 20.06.2015.

Artykuł wpłyną:

9 sierpnia $2017 \mathrm{r}$.

Zaakceptowano:

19 października 2017 r. 